\section{Kamayas \\ Derual Tenee Agana}

http://jayapanguspress.penerbit.org/index.php/kamaya

\title{
Ideologi Penggunaan Ketupat Krosok dalam Upacara Yadnya Umat Hindu \\ (Studi Di Desa Bengkel Kecamatan Kediri Kabupaten Tabanan)
}

\author{
Oleh: \\ I Made Girinata \\ Institut Hindu Dharma Negeri Denpasar \\ girinata71@gmail.com
}

\begin{tabular}{lr}
\hline Keywords: \\
\hline Idiology; Ketupat \\
Krosok; and \\
Yadnya \\
Ceremony \\
\hline
\end{tabular}

\begin{abstract}
Ketupat has an important function and meaning for the life of the Hindu community, especially in Bengkel Village, Kediri District, Tabanan Regency both in social and ritual aspects. The connotation of the diamond for the community for the means of the ceremony is the matting of coconut leaves which is filled with rice and then boiled until cooked like rice. But Bengkel Village, Kediri Subdistrict, Tabanan Regency also uses krosok ketupat for its yadnya ceremony, which is ketupat which contains halfcooked and dry rice. This research uses a qualitative approach, which is sourced from primary and secondary data. Collected with techniques: observation, interview, and document study. The use of krosok ketupat for the community in Bengkel Village, Kediri Subdistrict, Tabanan Regency is based on the existence of ideology as the principle of understanding the modernity of the community which is implemented through applying but not deviating from the teachings of Hinduism. The reason why the ketupat ketupat was used in the Yadnya ceremony was because of practical and economic considerations, buying cheaper than the process of making it, and was easily available at any time. The religious implications of using ketupat krosok for the people of Bengkel Village, Kediri District, Tabanan Regency, that the community's confidence in carrying out the ceremony of Yadnya did not recede and instead became more enthusiastic. The economic implication is that people who carry out their yad ceremonies are economically able to carry out their obligations to work with income that is more profitable than setting aside special time to make a diamond by leaving time to work. While the ideological implications, that the Bengkel Village community, Kediri Subdistrict, Tabanan Regency, in the era of globalization in carrying out religious ceremonial obligations show the existence of a simplicative idea of the use of diamonds. The use of ketupat in some forms of banten is simplified to become ketapap krosok, especially in banten when it is finished not to be diluted / thrown.
\end{abstract}


Kata Kunci:

Ideologi; Ketupat Krosok; dan Upacara Yadnya

\begin{abstract}
Abstrak
Ketupat memiliki fungsi dan makna penting bagi kehidupan masyarakat Hindu khususnya di Desa Bengkel, Kecamatan Kediri, Kabupaten Tabanan baik dalam aspek sosial maupun ritual. Konotasi ketupat bagi masyarakat untuk sarana upacara yadnya adalah anyaman dari daun kelapa yang di dalamnya diisi beras kemudian direbus hingga matang seperti nasi. Namun Desa Bengkel, Kecamatan Kediri, Kabupaten Tabanan juga menggunakan ketupat krosok untuk upacara yadnya yaitu ketupat yang isinya beras setengah matang dan sudah kering. Penelitian ini menggunakan pendekatan kualitatif, yang bersumber dari data primer dan data sekunder. Dikumpulkan dengan teknik: observasi, wawancara, dan studi dokumen. Penggunaan ketupat krosok bagi masyarakat di Desa Bengkel Kecamatan Kediri, Kabupaten Tabanan dilandasi adanya idiologi sebagai azas dari paham modernitas masyarakat yang diimplementasikan melalui menerapkan namun tidak menyimpang dari ajaran agama Hindu. Alasan ketupat krosok dipergunakan dalam upacara yadnya adalah karena pertimbangan praktis dan ekonomi, membeli lebih murah dari proses membuat, dan sewaktu-waktu mudah didapat. Implikasi religius penggunaan ketupat krosok bagi masyarakat Desa Bengkel, Kecamatan Kediri, Kabupaten Tabanan, bahwa keyakinan masyarakat dalam melaksanakan upacara yadnya tidak surut dan justru semakin antusias. Implikasi ekonomi bahwa masyarakat yang melaksanakan upacara yadnya secara ekonomi dapat menjalankan kewajibannya bekerja dengan pendapatan yang lebih menguntungkan dari pada menyisihkan waktu khusus membuat ketupat dengan meninggalkan waktu bekerja. Sedangkan implikasi ideologis, bahwa masyarakat Desa Bengkel, Kecamatan Kediri, Kabupaten Tabanan, di era globalisasi dalam menjalankan kewajiban upacara keagamaan menununjukkan adanya suatu gagasan simplikatif terhadap penggunaan ketupat. Penggunaan ketupat dalam beberapa bentuk banten disederhanakan menjadi ketutap krosok, terutama pada banten ketika selesai dipersembahkan tidak dilungsur/ dibuang.
\end{abstract}

\section{Pendahuluan}

Tatanan kehidupan masyarakat Bali (Hindu), menunjukkan ritual menjadi bagian penting dari cara-cara anggota masyarakat mengekspresikan emosinya, memelihara dan memperbaiki dunia kehidupannya, serta cara-cara mereka menolak atau mengatasi berbagai masalah atau bahaya dalam beradaptasi dengan lingkungannya. Keseluruhan cara itu terformulasi ke dalam lima bentuk upacara (panca yadnya). Selanjutnya teraplikasi dalam berbagai tahapan dan tingkatan upacara yadnya, dan setiap tahapan 
serta tingkatan diyakini mengandung nilai yang mampu dapat memperbaiki serta mengatasi masalah kehidupannya.

Nilai adalah sesuatu yang dianggap paling berharga dalam kehidupan masyarakat pada jamannya berupa pandangan mengenai hal yang luhur diyakini sebagai representasi komitmen moral bagi para anggota komunitas tertentu yang dijadikan acuan dalam hidup bersama sehingga menjadi kewajiban bagi setiap anggota untuk memelihara, melestarikan, dan memaknainya dengan cara yang paling baik menurut ukuran mereka.

Seperti halnya penggunaan ketupat bagi umat Hindu (Bali), masih diyakini sebagai salah satu media dalam mengatasi suatu masalah yang sebelumnya tidak bisa diatasi secara logika. Pelaksanaan upacara yadnya yang dilaksanakan oleh umat Hindu (Bali) hampir semuanya mempergunakan ketupat. Berbagai jenis dan bentuk ketupat dikenal oleh umat Hindu dengan fungsinya masing-masing seperti: tipat dampul, tipat taluh, tipat gong, tipat nasi, tipat kukur, tipat galeng dan lain-lainnya. Ada venomena menarik di Desa Bengkel, Kecamatan Kediri, Kabupaten Tabanan, bahwa dalam upacara yadnya masyarakat menggunakan ketupat krosok yaitu ketupat yang hanya berisi beras tanpa direbus bahkan bentuk ketupatnya daun kelapa yang sudah kering.

\section{Metode}

Agar penelitian tidak melenceng dari masalah, maka dibingkai dengan beberapa hasil penelitian terdahulu yang sesuai dan berdasarkan variabel yang ditetapkan dalam judul penelitian. Masalah dibedah dengan teori secara eklektik mempergunakan teori teori fungsional struktural dari Talcott Parsons, teori religi dari Koentjaraningrat, dan teori simbol dari Turner. Penelitian ini menggunakan pendekatan kualitatif, yang bersumber dari data primer dan data sekunder. Dikumpulkan dengan teknik: observasi, wawancara, dan studi dokumen. Selanjutnya dianalisis dengan cara deskriptif kualitatif dan interpretatif dan tahapan terakhir dilakukan penyajian hasil penelitian.

\section{Hasil dan Pembahasan}

\section{Gambaran Umum Lokasi Penelitian}

Desa Bengkel termasuk Wilayah Kecamatan Kediri, Kabupaten Tabanan, Provinsi Bali. Letaknya $10 \mathrm{~km}$ sebelah Selatan kota Tabanan dan $29 \mathrm{~km}$ dari kota Denpasar. Iklim Desa Bengkel tidak jauh berbeda dengan iklim Pulau Bali pada 
umumnya, yang dipengaruhi oleh angin musom yang mengakibatkan adanya iklim/musim kemarau dan musim hujan. Brdasarkan data statistik jumlah penduduk Desa Bengkel tahun 2019 jumlah penduduk Desa Bengkel sebanyak 2239 jiwa.

\section{Jenis-Jenis Ketupat}

Ada beberapa jenis tupat yang digunakan dalam pelaksanaan upacara keagamaan khususnya di Desa Bengkel Kecamatan Kediri, Kabupaten Tabanan.

\section{a. Tupat Dampulan}

Tupat dampulan adalah simbol kura-kura atau penyu bertelur. Tupat dampulan mengandung makna edukatif yaitu mengingatkan kepada umat manusia bahwa jiwa seseorang yang digodok dengan berbagai pengalaman hidup, dan dihadapkan pada keadaan suka maupun duka. Kematangan jiwa ini disimbolkan dengan sifat-sifat kedewasaan. Apa yang dialaminya selama ini diterimanya dengan lapang dada.

\section{b. Tupat Nasi/Kelanan}

Ketupat Nasi/kelanan adalah lambang dari Sad Ripu yang telah dapat dikendalikan oleh manusia. Dengan terkendalinya Sad Ripu maka manusia dapat menjalani kehidupan dengan keseimbangan. Tupat kelanan umumnya berjumlah enam biji berbentuk segi empat bujur sangkar. Ketupat Kelanan merupakan ketupat yang berbentuk segi empat bujur sangkar, dipergunakan untuk Banten Sodan, Banten Pekeling. Dalam kehidupan social, ketupat ini umumnya dikomodifikasi oleh para pedagang makanan dengan sebutan tupat cantok.

c. Tupat Sirikan

Tupat Sirikan umumnya dipergunakan untuk upacara mejauman, yaitu pada proses upacara mapamit yang lebih dikenal dengan banten tupat bantal. Karena pada upacara ini tupat sirikan dan jajan bantal merupakan unsur yang paling utama. Tupat Sirikan juga dipergunakan untuk kematian (orang meninggal) hampir sama dengan banten tupat sirikan untuk upacara perkawinan (mejauman). Hanya saja tempatnya dibedakan, yaitu jika pada waktu mejauman banten tupat sirikan itu tempat atau alasnya adalah keben, sedangkan untuk upacara kematian tempat atau alasnya dari klakat.

\section{d. Tupat Pusuh}

Bentuknya seperti segi tiga dengan tonjolan - tonjolan sisi yang begitu runcing. Ketupat ini biasanya digunakan dalam suatu upacara pembersihan yang di taruh di 
dalam lis (ikatan janur tradisi di Bali) dan yang paling unik untuk ketupat ini adalah ada tradisi sebagai obat yaitu, obat mata kelilipan dengan cara mengancungkan ke arah mata tiga kali.

\section{e. Tupat Gong}

Tupat ini sebagai inti dalam banten pejati yang digunakan sebagai sarana upacara pada perangkat gambelan seperti gong, angklung, gender, dan bentuk gambelan lainnya yang dipersembahkan ketika akan mulai dimainkan (nabuh). Tupat gong juga oleh masyarakat umat Hindu (Bali) diyakini sebagai simbol mapinunas (memohon), kesembuhan bagi masyarakat yang sedang menderita penyakit gendongan (sejenis gondok). Simbol lain juga digunakan untuk memohon secara ritual apabila ada anak kecil (bayi) lama belum bisa berbicara, dihaturkan pada sebuah perangkat gambelan (gong) dituntun oleh seorang Pinandita. Tupat gong lengkap dengan pejati juga diyakini sebagai kaul untuk menemukan suatu barang yang susah ditemukan (hilang).

f. Tupat Sari

Ketupat Sari merupakan ketupat yang berbentuk seperti gunung/payudara wanita, ketupat ini biasanya dihaturkan pada saat Soma Ribek yaitu dua hari setelah hari Saraswati dan bisa juga dihaturkan pada saat sehari setelah Banyu Pinaruh.

g. Tupat Taluh

Ketupat Taluh merupakan Ketupat yang bentuknya menyerupai telur, Ketupat ini digunakan sebagai tempat telur pada Banten Daksina. Tupat ini digunakan dalam upacara di sawah yaitu upacara mabiyu kukung ketika padi sudah mulai menguning.

\section{Penggunaan Ketupat Krosok pada Upacara Yadnya di Desa Bengkel, kecamatan Kediri, Kabupaten Tabanan}

Masyarakat Desa Bengkel, Kecamatan Kediri, Kabupaten Tabanan sebagai umat Hindu dalam mengimplementasikan ajaran keagamaan mengacu pada ketentuan yang ditetapkan pada Eka Likita Desa dan penterapannya dijalankan oleh pimpinan lembaga desa pakraman. Menurut Perbekel Desa Bengkel (wawancara Mei 2019) menjelaskan bahwa masyarakat dengan agama tak bisa dilepaskan dan merupakan dwi tunggal kalau diibaratkan sebagai diri manusia. Antara desa pakraman dan warga masyarakat diibaratkan sebagai purusa dan pradana, atau stula dan atma sarira. Agama diibaratkan sebagai jiwa desa pakraman, sedangkan desa pakraman ibarat badan agama. Oleh karena itu, masyarakat Desa Bengkel juga berkomitmen berusaha menjaga keharmonisan 
hubungan antara keduanya berdasarkan falsafat tri hita karana yang terimplementasi pada tiga sasaran berikut: 1) Hubungan warga masyarakat terhadap Ida Sang Hyang Widhi Wasa, 2) Hubungan warga masyarakat dengan sesama warga dan orang lain diwujudkan dengan menjaga persatuan dan kesatuan. 3) Hubungan warga masyarakat terhadap lingkungan alam.

Harmonisasi tata pelaksanaan keagamaan di Desa Bengkel sampai saat sekarang disebabkan oleh antuasias seluruh warga masyarakat menjunjung aturan yang tersusun, baik dalam bentuk awig-awig maupun pararem. Selain itu, juga petunjuk dari lembaga umat Parisada Hindu Dharma Indonesia. Menurut Winarcana (wawancara, 3 Juni 2019) menerangkan bahwa kehidupan sosial keagamaan umat Hindu di Desa Bengkel menjunjung tinggi ajaran agama yang disebut dengan tat twam asi. Ajaran tat twam asi mengandung nilai-nilai susila yang dapat menimbulkan sikap toleransi, baik dalam pikiran, perkataan, maupun perbuatan. Dengan pemahaman masyarakat terhadap ajaran tat twam asi solidaritas umat lebih berkembang sehingga tercipta hubungan yang harmonis di antara sesama makhluk ciptaan Tuhan.

Desa Bengkel dalam menjalankan aktivitas keagamaannya tidak bisa lepas dari ketentuan-ketentuan yang telah ditetapkan Parisada Hindu Dharma Indonesia (PHDI), dengan aktif melakukan koordinasi secara langsung, terutama dengan PHDI di tingkat Kabupaten Tabanan. Sebagaimana penjelasan dari Jro Mangku Gede Wisna (wawancara, 9 September 2019) menjelaskan bahwa segala upacara keagamaan yang dilaksanakan masyarakat Desa Bengkel secara vertikal upacara yadnya dalam Panca Yadnya sebagai bentuk persembahan dilaksanakan dalam konteks etika religius merupakan persembahan ka luhur (atas) dan ka sor (bawah). Ke duanya bermakna agar mendapatkan suatu keselamatan. Ka luhur (atas) dikonotasikan sebagai suatu persembahan dan ucapan terimakasih kepada Ida Sang Hyang Widhi Wasa dengan segala manifestasi-Nya agar beliau menganugerahkan keselamatan kepada umat manusia dalam menjalankan segala kewajiban. Sedangkan untuk yang $\mathrm{ka}$ sor (bawah) adalah persembahan yang ditujukan kepada mahluk bawahan (bhuta kala) agar menunjukkan sifat-sifat kedewataannya dan tidak mengganggu aktivitas manusia. Banten yang dipersembahkan baik ka luhur (ke atas) maupun ka sor (bawah) beberapa diantaranya menggunakan sarana ketupat. Adapun jenis-jenis banten yang menggunakan ketupat adalah : banten pejati, banten pengambeyan, panyeneng, banten caru, dan sebagainya. 
Menurut Gede Oka menjelaskan yening masyarakat driki sampun biasa ngangge ketupat krosok ritatkala ngelaksanayang upacara yadnya. Sakewanten nenten sami banten ngangge ketupat krosok, katupat biasa sane lebeng tetep meangge utaminyane ring banten sane munggah ka luhur inggih punika banten pejati (Wawancara, 17 September 2019).

Makna dari penjelasan narasumber di atas menjelaskan bahwa masyarakat Desa Bengkel sudah biasa menggunakan ketupat krosok ketika melaksanakan upacara yadnya. Tetapi tidak semua banten menggunakan ketupat krosok. Ketupat biasa juga tetap dipergunakan terutama untuk banten yang dipersembahkan kaluhur (ke atas/ Ida Sang Hyang Widhi Wasa) yaitu pada banten pejati. Chambers (1983), menjelaskan bahwa masyarakat Bali memiliki pengetahuan dan teknologi tradisional yang disebut "pengetahuan rakyat pedesaan" yang diwariskan dari generasi ke genarssi sehingga membentuk suatu tradisi, dan dalam pemertahanannya melibatkan pada ritual. Namun dalam perkembangan selanjutnya ditengah arus modernisasi yang diperkuat masuknya budaya barat dan keterlibatan pekerjaan masyarakat yang sama antara laki-laki dan perempuan, beberapa tradisi masyarakat Bali diadaptasi, dimarjinalkan, karena dipandang perlu dilakukan suatu transformasi. Hal itu dilakukan karena dijaman modernisasi, tradisi sering dipahami sebagai bagian dari masalah, sehingga penyelesaiannya perlu dilakukan reformasi. Seperti pendapat Chambers diatas, sudah terjadi di Desa Bengkel, Kecamatan Kediri,Kabupaten Tabanan terkait dengan tatacara melaksanakan upacara yadnya terutama pada bentuk sarana persembahan.

\section{Alasan Penggunaan Ketupat Krosok Bagi Masyarakat Hindu Desa Bengkel, Kecamatan Kediri, Kabupaten Tabanan}

Umat Hindu di Bali pada umumnya, setiap melaksanakan upacara keagamaan selalu dilandasi dengan petunjuk sastra. Dalam setiap upacara baik yang dilaksanakan secara pribadi maupun melibatkan masyarakat, sangat perlu ditekankan pada landasan kesusilaan. Sebab semakin besar suatu yadnya yang dipersembahkan, semakin berat pula pengendalian diri yang patut dilakukan. Apabila sikap dan perilaku sudah benar dalam melaksanakan upacara yadnya, maka semua sarana dan prasarana upacara merupakan wujud Dewata (manifestasi Tuhan). Bermaknanya suatu upacara yadnya bukan ditentukan oleh kwantitas (besar kecilnya atau banyak sedikitnya sarana dan prasarana), akan tetapi sangat dipengaruhi oleh kwalitas (bobot) kesuciannya. 
Uraian di atas, dengan jelas menekankan bahwa kesuksesan daripada yadnya sangat ditentukan oleh sikap dan prilaku dari tiga unsur penting (Tri Manggalaning Yadnya) yaitu orang yang melaksanakan yadnya, orang yang membuat sesajen dan orang yang memimpin jalannya upacara yadnya. Ketiga unsur itu harus dapat bekerja sama secara sinergis. Penggunaan ketupat krosok dalam upacara bagi masyarakat Hindu di Desa Bengkel, Kecamatan Kediri, Kabupaten Tabanan tidak dilandasi atas petunjuk sastra, namun sangat diyakini maknanya sampai saat ini. Namun tidak semua jenis banten yang menggunakan tupat dipergunakan ketupat krosok, melainkan penggunaan ketupat biasa (rebusan beras matang) masih mendominasi penggunaannya baik dalam rangkaian upacara panca yadnya maupun aktifitas ritual terkait dengan kekuatan supernatural untuk keselamatan manusia. Alasan masyarakat Desa Bengkel menggunakan ketupat krosok adalah:

\section{a. Alasan Ekonomi}

Menurut (Ardika, 2008) pertumbuhan ekonomi yang cukup cepat mendorong individu/anggota masyarakat untuk lebih bersifat efisien dalam menekuni pekerjaan tertentu (spesialis) dan perdagangan. Bersamaan dengan itu, maka pembagian tenaga kerja akan semakin meluas dalam masyarakat sehingga pada gilirannya hal ini menimbulkan tatanan masyarakat yang bersifat lebih kompleks.

Secara harfiah bisnis diartikan sebagai suatu kegiatan yang bersifat mencari keuntungan. Secara konseptual bisnis orang Bali tidak lepas dari pergulatan tujuan hidup orang Bali menurut pandangan Hindu. Tujuan hidup tersebut adalah jagadhita dan moksa. Jagadhita adalah kebahagiaan tertinggi yang dapat dicapai oleh manusia dalam kehidupan di dunia, seperti yang tersimpul dari dharma, artha, kama (Tri Purusartha). Kebahagiaan materi ekonomi-teknologi (artha) dan kebahagiaan psikologi (kama) seperti kasih sayang, cinta, pujian, kemasyuran, dan lain-lainnya seyogyanya pencapaiannya bersandarkan dharma.

Radhakrisnan (dalam Sudibya, 1994) menjelaskan melalui keempat disiplin hidup yaitu Catur Purusa Artha (dharma, artha, kama, moksa), Catur Asrama (brahmacari, grhasta, wanaprasta, sanyasin), manusia Hindu mencapai tujuannya yaitu penemuan manusia akan jiwanya, dari penemuan ini akan diperoleh keselamatan di jalan Tuhan. Sistem ekonomi Hindu adalah ekonomi yang landasan falsafahnya merupakan rangkuman nilai yang terdiri atas kesejahteraan bersama, keharmonisan, persatuan, dan 
perdamaian. Dalam hal ini setiap manusia sebagai pelaku memiliki keterkaitan untuk menjalankan disiplin Catur Purusa Artha, dan Catur Asrama.

Secara internal warga masyarakat Desa Bengkel yang melakukan bisnis menjual perlengkapan banten upacara (tupat krosok) dipandang sebagai peluang yang terbentang di depan mata untuk melakukan bisnis ditengah kesibukan masyarakat modernitas yang terikat dengan waktu. Ideologi kapitalis telah diterapkan oleh sejumlah masyarakat sejalan dengan hakikat globalisasi, yakni bersendikan ideologi pasar atau logika pasar. Dalam kontestasi ini secara ekonomi masyarakat penjual merasa mendapat keuntungan di lain sisi masyarakat yang melaksanakan upacara yadnya (pembeli) juga merasa diuntungkan karena tidak sampai membuang waktu kerja untuk mempersiapkan sarana banten karena sudah tersedia di tempat jualan (warung).

\section{b. Pengaruh Sosial}

Adanya kekuatan pasar yang mempengaruhi masyarakat Desa Bengkel yang sebagian besar bekerja di sektor pariwisata menyebabkan mereka melaksanakan aktivitas pelaksanaan upacara agama menunjukkan adanya kepraktisan dan efisiensi dengan membeli sarana banten. Hal itu juga terjadi karena lingkungan sosial. Masyarakat telah terbawa pada satu model gaya hidup modern untuk mampu menunjukkan pencitraan diri, dengan membeli banten akan dapat mengangkat arkat dan bartabatnya dalam status sosial.

Kondisi seperti itu akhirnya mendukung terlaksananya komodifikasi telah dimanfaatkan oleh para tukang banten/ sarati banten sebagai aktor untuk mengatur dan mengemas secara bagus produksi atau komoditi dan mendistribusikannya kepada pihak pemesan (konsumen). Salah satunya karena ketupat krosok paling banyak dipergunakan dalamupacara yadnya, sehingga pemajangan ketupat krosok sebagai bahan dagangan banyaktersedia di warung-warung.

Konsumtivisme maupun konsumerisme sebenarnya sudah sejak lama ada karena kedua isme ini ternyata sudah lama ada dan sejak awal telah mengakar kuat dalam kemanusiaan kita (our humanity). Dalam ranah masyarakat konsumer hasrat direproduksi lewat ide-ide yang terbentuk melalui proses sosial. Baudrilard melihat bahwa struktur nilai yang tercipta secara diskursif menentukan kehadiran hasrat. Struktur nilai dalam realitas masyarakat konsumer ini menurutnya mengejawantah dalam kode-kode. Produksi tidak lagi menciptakan materi sebagai materi eksternal, produksi menciptakan materi sebagai kode-kode yang menstimulasi kebutuhan atau hasrat sebagai objek internal konsumsi. Dalam nalar Freudian hasrat untuk mengonsumsi secara mendasar 
adalah sesuatu yang bersifat instingtual. Ia berada dalam fase pertama perkembangan struktur psikis manusia yaitu id. Dalam fase ini semua tindakan mengacu atau didasari oleh prinsip kesenangan-kesenangan yang bersifat spontan. Tindakan manusia untuk mencapai kepuasan dan kesenangan spontan ini dalam fase id bersifat irasional. Mengonsumsi pada awalnya terkait dengan tindakan menggapai kepuasan secara irasional, spontan, dan temporal-fase id struktur psikis manusia

Komodifikasi ketupat krosok di Desa Bengkel dalam era global didominasi secara struktural oleh mereka yang memiliki modal ekonomi dan modal politik. Produsen dalam hal ini sarati banten (tukang banten) memiliki modal ekonomi sekaligus modal politik. Oleh karena tidak semua warga masyarakat bisa membuat banten secara lengkap di samping karena ada persyaratan religusitas, maka dengan politik kemampuannya, sarati banten (tukang banten) dapat memainkan pasar dalam satu arena untuk pelaksanaan upacara yadnya.

Masyarakat masyarakat Desa Bengkel, Kecamatan Kediri, Kabupaten Tabanan adalah masyarakat global dengan cirinya terbuka terhadap segala hal yang baru termasuk perubahan. Hal ini berimplikasi pada kecenderungan masyarakat menjadi konsumen daripada menjadi produsen budaya. Proses produksi dan distribusi ketupat krosok dikuasai agen-agen kapitalisme yang memiliki keahlian dalam membuat banten dan otoritas sebagai sarati.

Produk ketupat krosok menjadi alat komoditi bersama-sama dengan komoditi lainnya yang dibungkus dengan tujuan membantu masyarakat Desa Bengkel atau umat Hindu yang sedikit memiliki waktu dalam melaksanakan upacara yadnya sehingga tinggal membele di warung atau menyerahkan kepada sarati (tukang banten)

Marx memberi makna bahwa melalui kerja dihasilkan suatu produk dan apa pun yang diproduksi untuk diperjualbelikan. Produk kerja yang dibuat bukan untuk digunakan, tetapi untuk diperjualbelikan sebagai sebuah komoditas. Produk tidak hanya penting untuk dipakai, tetapi juga berdaya jual. Nilai dan nilai guna suatu benda adalah sisi kembar dari komoditas yang saling berlawanan. Nilai guna (use value) sebuah objek telah berubah menjadi nilai tukar (exchange value) di pasar. Dalam hal ini ketupat krosok sebagai objek produksi berperan sebagai komoditas yakni dijadikan barang yang dapat diperjualbelikan. 


\section{Implikasi Penggunaan Ketupat Kerosok Bagi Umat Hindu di Desa Bengkel Kecamatan Kediri, Kabupaten Tabanan}

Makna kata implikasi akan menjadi landasan penting dalam penelitian ini untuk mengetahui konsekuensi akhir dampak atau akibat dari penggunaan ketupat krosok yang berdampak baik dalam status individu maupun kolektif. Penelitian ini terfokus pada terjadinya implikasi dari penggunaan tupat krosok terhadap aspek religius magis, ekonomi, sosial budaya, dan ideologis pada masyarakat Desa Bengkel, Kecamatan Kediri, Kabupaten Tabanan, sebagai berikut.

\section{a. Implikasi Religius}

Gencarnya perkembangan pariwisata tampaknya juga mengikuti bergeraknya kompleksitas arus perubahan sosial masyarakat tradisional ke masyarakat modern. Menurut (Sztompka, 2007) perubahan fundamental di dunia ini ditandai oleh munculnya tatanan masyarkat urban, industrial, dan kapitalis. Dari pendapat itu pula menunjukkan bahwa industri pariwisata telah mengubah dinamika tatanan sosioreligius desa-desa pakraman di Bali salah satunya Desa Bengkel, Kecamatan Kediri, Kabupaten Tabanan yang lokasinya beririsan dengan objek wisata Tanah Lot.

Pariwisata telah memengaruhi segala aspek kehidupan masyarakat, baik ekonomi, sosial, politik, maupun budaya sejalan dengan pengembangan pariwisata budaya. Namun di sisi lain juga mendorong tumbuhnya kesadaran kritis krama desa pakraman terhadap dinamika pariwisata budaya. Hal itu sejalan dengan pendapat (Pitana, 1994) bahwa pariwisata budaya merupakan salah satu bentuk industri budaya. Dikatakan demikian karena telah memanfaatkan berbagai aspek kebudayaan secara massal dalam suatu sistem produksi yang mencakup aspek produksi, reproduksi, konsumsi, dan promosi. Dengan demikian, masyarakat terdorong utuk melakukan perubahan sistem kehidupan yang lebih menekankan pada inovasi.

Inovasi perubahan sistem kehidupan masyarakat Desa Bengkel yang menggunakan ketupat krosok dalam beberapa pelaksanaan upacara yadnya sejalan dengan pendapat (Sztompka, 2007) yaitu memiliki orientasi dan harapan ke masa depan sesuai dengan konteks lokal dan global yang melingkupinya pada hubungan yang dialektif reflektif. Perubahan di lakukan untuk mengatasi kelemahan menjadi kekuatan sehingga merupakan proses mengatasi masalah, mengubah kelemahan menjadi kapasitas, mengubah bentuk tanpa harus mengganti isinya. 
Gede Oka (wawancara, 10-10-2019) menjelaskan secara tegas mengakui bahwa dengan meyakini makna religius, maka perubahan dalam prosesi upacara yadnya dengan menggunakan beberapa sarana ketupat krosok yang dilakukan selama ini bagi masyarakat dirasakan tidak menyimpang dari norma dan tata nilai ajaran agama Hindu (Wawancara, 10 Oktober 2019).

Lubis (2006) juga mengakui bahwa agama atau praktik budaya yang bersifat religius pada intinya merupakan wujud keinginan untuk mengubah, baik mengubah manusia para pengikutnya dari manusia yang sesat menjadi insan yang benar maupun mengembalikan yang tersesat menjadi insan yang benar dan mengajak umat mencapai keselamatan. Fenomena ini disebut dengan istilah adaptive culture, artinya porsi dari budaya nonmaterial (norma, nilai, dan kepercayaan) dapat mendorong terjadinya perubahan dan menyesuaikan pada inovasi material dengan cara yang cerdas dan konstruktif.

Penggunaan ketupat krosok dalam beberapa jenis banten juga diakui oleh Suciani mejelaskan, walaupun menggunakan ketupatkrosok namun masyarakat Desa Bengkel tetap dapat menjaga makna religius dalam upacara yadnya. Hal itu dapat dibuktikan bahwa masyarakat dijaman era globalisasi ini volume masyarakat dalam melaksanakan upacara yadnya dan dengan ekspresi yang justru semakin meningkat. Karena ketersediaan beberapa sarana prasarana upacara yadnya dapat ditemukan setiap saat dalam bentuk sudah jadi. Aktivitas religius di Desa Bengkel justru tampak semakin meriah dan krama desa juga semakin sadar serta bergairah mengikuti setiap prosesi upacara. Selama bekerja warga masyarakat benar-benar merasakan suatu suasana kekeluargaan tanpa membedakan status (Wawancara, 15 Oktober 2019).

Sikap kebersamaan dan penuh kegembiraan yang terjadi di Desa Bengkel seperti itu menurut (Mangunwijaya, 1982) merupakan sikap dewasa kaum beragama dalam iman dan amalnya, yang akhirnya berkembang menjadi masyarakat religius, sebagaimana terlihat pada Gambar 1 berikut. 


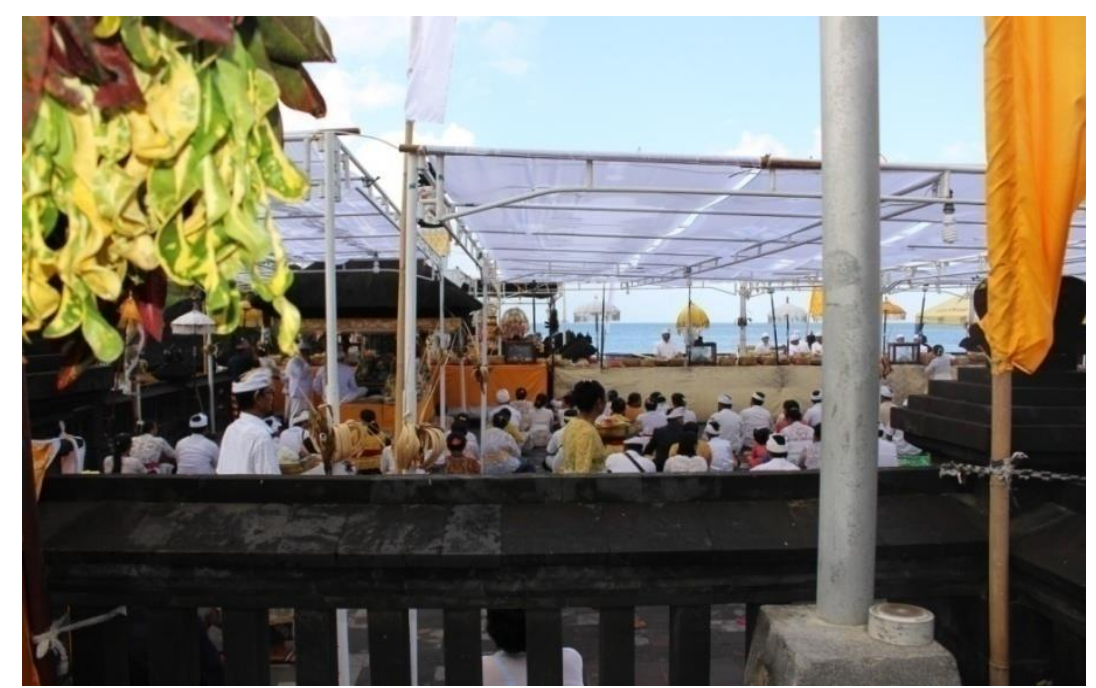

Gambar 1

Prosesi Upacara Odalan di Pura Dalem (Koleksi, Girinata, 2019)

Menurut Jero Mangku Gede Wisna menjelaskan kemeriahan dan kegairahan tersebut memang bukan merupakan hal yang bersifat hura-hura, melainkan sebagai wujud rasa bhakti (sujud dengan hati suci) krama desa kepada Sang Hyang Widhi. Mereka berkeyakinan bahwa jika masyarakat bhakti melaksanakan yadnya, maka Sang Hyang Widhi juga sweca (berkenan) melimpahkan keselamatan dan kesejahteraan kepada masyarakat (Wawancara, 9 Oktober 2019). Menurut Eiseman (1989), keyakinan orang Bali tentang sekala dan niskala ini dengan istilah "spatial and spiritual orientation", artinya perbedaan itu tidak dimaknai sebagai sebuah perbedaan yang eksklusif, terpisah satu sama lain, tetapi perbedaan yang memiliki orientasi spiritual yang utuh untuk menciptakan kehidupan yang seimbang. Seperti semua arah mata angin di Bali, kangin (timur) - kauh (barat), kaja (utara) - kelod (selatan), dan luhur (atas) - sor (bawah) masing-masing memiliki orientasi spiritual untuk menjaga keseimbangan alam semesta. Saat semua unsur arah mata angin yang berbeda dan berlawanan ini menjadi satu kesatuan di tengah-tengah, maka lahirlah kehidupan yang harmonis, seimbang, dan tenteram penuh spiritualitas. Dari pernyataan itu, terkait dengan kemampuan yang dimiliki oleh krama Desa Bengkel Kecamatan Kediri, Kabupaten Tabanan untuk menghayati dan mengamalkan makna rwa bhineda penggunaan ketupat krosok dalam aktivitas ritual yang sakral tetap berjalan harmonis sampai sekarang. 
Pernyataan itu dipertegas oleh Norwik Adi Sanjaya (wawancara, 19 Oktober 2019) yang menjelaskan masyarakat Desa Bengkel melaksanakan yadnya bukan dalam makna persembahan dan ungkapan rasa syukur ke hadapan Ida Sang Hyang Widhi Wasa serta manifestasiNya dan terhadap kepada para kekuatan Bhuta Kala. Namun juga sebaliknya apa yang dipersembahkan dimaknai sebagai simbol anugerah Ida Sang Hyang Widhi Wasa serta manifestasiNya bagi umat yang melaksanakan upacara yadnya. Sehingga sarana-sarana persembahan dalam bentuk makanan wajib dan patut dilungsur (dinikmati) setelah selesai prosesi upacara yadnya. Untuk itu atas pertimbangan etika religius persembahan yang ditujukan ke luhur (atas) untuk Ida Sang Hyang Widhi Wasa yang nantinya dilungsur (dinikmati) dipersembahkan menggunakan bahan-bahan makanan yang segar seperti ketupat matang biasa. Sedangkan untuk persembahan ke sor (bawah) boleh menggunakan sarana yang tidak segar seperti ketupat krosok. Karena secara psikologis persembahan ke sor (bawah) merupakan persembahan terhadap para bhuta kala yang dimaknai bukan sebagai anugerah, melainkan persembahan atas kebaikan dari umat untuk meningkatkan derajat bhuta kala menjadi sifat-sifat kedewataan.

\section{b. Implikasi Ekonomi}

Derasnya arus globalisasi menjadikan kondisi masyarakat Bali mengalami komodifikasi yang holistik tak terkecuali pada tatanan berupacara yadnya, sehingga orang Bali sangat kuat berpegang pada ideologi pasar. Ideologi ini menekankan pada gagasan bahwa pasar dan uang memiliki peranan penting dalam kehidupan manusia. Kepemilikan uang mengharuskan manusia untuk memiliki pekerjaan swdangkan pekerjaan sulit diperoleh. Namun bagi masyarakat di Desa Bengkel, selain pekerjaan di sektor pertanian, maka pekerjaan membuat sarana upacara adalah suatu propesi bisnis yang menjanjikan.

Bekerja adalah untuk memenuhi kebutuhan dan kebutuhan manusia yang paling dasar yaitu (1) kebutuhan fisik adalah kebutuhan akan sandang, pangan, papan, dan kebutuhan biologis; (2) kebutuhan sosial adalah kebutuhan akan menerima dan diterima dalam pergaulan hidup di masyarakat; dan (3) kebutuhan filosofis adalah kebutuhan akan pendidikan dan kebudayaan di dalamnya termasuk hidup beragama. Apabila ketiga kebutuhan tersebut dapat dipenuhi, maka mereka dikatakan hidup sejahtera (Wiana, 2006).

Penggunaan ketupat krosok dalam pelaksanaan upacara yadnya memberikan kontribusi terhadap kehidupan perekonomian masyarakat Desa Bengkel, baik sebagai 
individu yang melaksaakan upacara yadnya, para tukang banten/sarati maupun para pedagang sarana upacara di pasar Desa Bengkel. Undang-Undang Nomor 13 Tahun 2003 Pasal 1 Ayat (2) menguraikan tentang ketenagakerjaan dinyatakan bahwa tenaga kerja adalah setiap orang yang mampu melakukan pekerjaan guna menghasilkan barang dan atau jasa untuk memenuhi kebutuhan sendiri dan untuk masyarakat. Dalam perusahaan atau industri, baik yang berbadan hukum maupun yang tidak tentu akan mempekerjakan pekerja untuk menggerakkan aktivitas usahanya sesuai dengan fungsi, bidang, dan keahliannya.

Picard (2006) menjelaskan bahwa, bidang profesi yang bersifat modern, menimbulkan berbagai ketegangan sosial, karena mencerminkan pola hidup yang bertolak belakang dengan kewajiban kolektif tradisional. Dapat dimaklumi bahwa para manajer/pimpinan enggan membiarkan para karyawannya pulang kampung setiap akan melaksanakan upacara yadnya dan juga sebagai anggota organisasi masyarakat dituntut kehadirannya dalam upacara adat dan agama. Mereka sering didenda secara adat karena tidak dapat ikut kegiatan-kegiatan adat dan keagamaan. Kondisi seperti inipun terjadi di Desa Bengkel, Kecamatan Kediri, Kabupaten Tabanan.

Atas kondisi seperti itu masyarakat Desa Bengkel melakukan inovasi terhadap mempersiapkan sarana kelengkapan upacara yadnya salah satunya adalah ketupat yang hampir sebagian besar dipergunakan dalam banten. Selanjutnya sampai saat sekarang hanya beberapa jenis banten yang dilengkapi dengan ketupat biasa (dibuat dengan rebusan beras matan) seperti untuk banten pejati, sedangkan banten-banten lainnya dipergunaan ketupat krosok (ketupat yang direbus setengah matang). Ketupat krosok bisanya dibuat jauh hari sebelum melaksanakan upacara yadnya dan bisa didapat dari para pedagang/ penjual banten. Menurut Suciani (Wawancara Tanggal 15 September 2019) menuturkan:

tityang medagang alat-alat banten niki liyan ring ngereh amerta, taler mapitulung marep ring warga masyarakat sane sibuk-sibuk sangkaning mekarya dini ditu. Ipun ten maduwe waktu mekarya banten tur ten maduwe busung nika mawinan tityang mautsaha medagang alat-alat banten sekadi lis, daksina, klatkat, ketupat (krosok) lan sane tiyosan . 


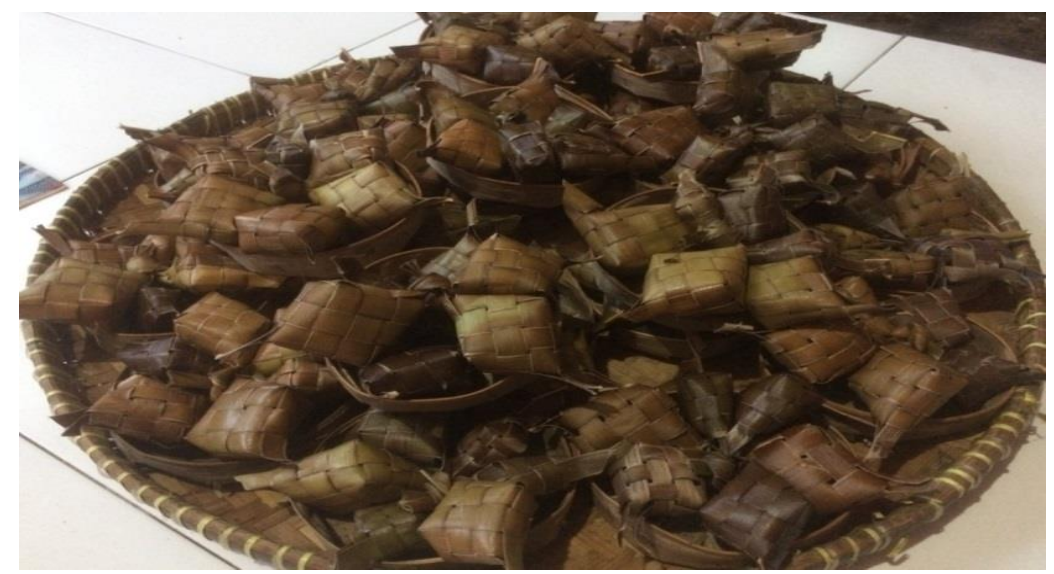

Gambar 2

Ketupat Krosok, (Dok. Girinata, 2019)

Pernyataan di atas mengandung makna bahwa selaku produsen (dagang) menjadikan peluang mencari keuntungan terhadap masyarakat yang tidak punya waktu karena sibuk bekerja dan tidak punya bahan untuk membuat banten. Atas dasar itu menjadi peluang bisnis mengais rejeki bagi para pedagang untuk menjual alat-alat seperti lis, daksina, klatkat, ketupat (krosok), dan yang lainnya.

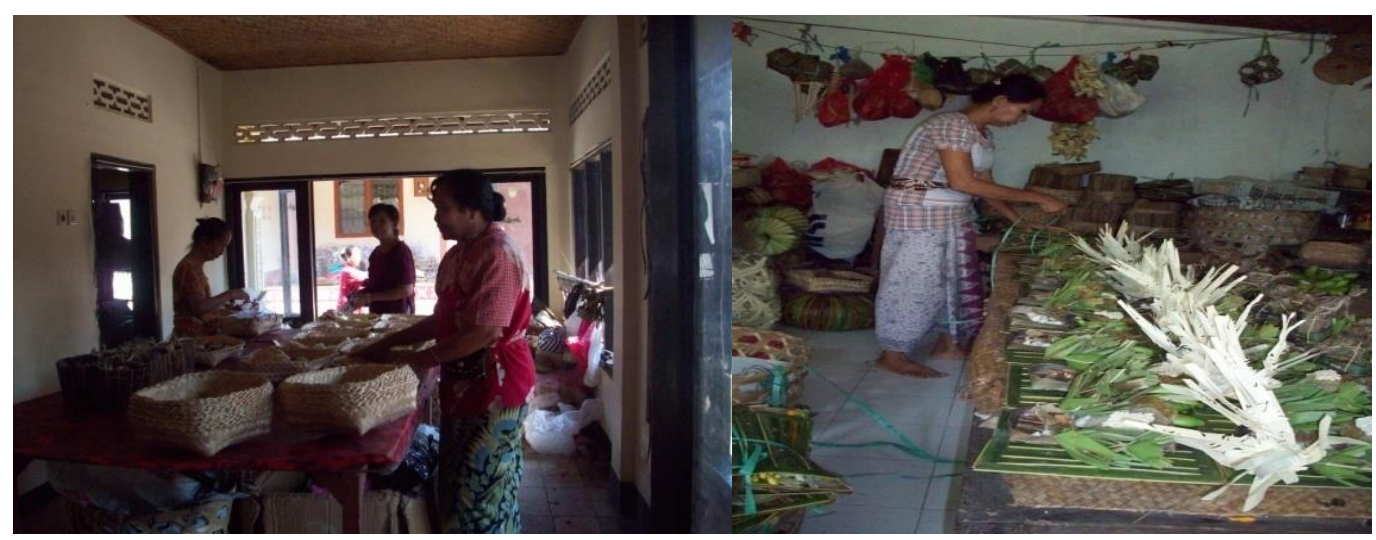

Gambar 3

Para sarati sedang Metanding, (Dok: Girinata, 2019)

Adnyana (2011) mengatakan bahwa dalam komersialisasi sarana maupun banten terdapat keuntungan yang diperoleh baik dari sisi penjual dan pembeli. Sang penjual mendapat untung dan pekerjaan sedangkan sang pembeli mendapat kemudahan. Bisnis banten adalah sebuah usaha yang menjanjikan karena berdampak positif yaitu mengurangi pengangguran dan mendatangkan lapangan pekerjaan yang baru. Dengan membeli ketupat krosok, maka umat Hindu di Desa Bengkel, Kecamatan Kediri, 
Kabupaten Tabanan yang sibukdan terikat dengan kerja telah terbantu dari sisi waktu, karena mereka masih tetap bekerja dengan tidak mengalami pemotongan penghasilan di tempatnya bekerja. Atmaja (2009) kebutuhan akan uang guna mendanai kebutuhan dasar dan gaya hidup yang kian berat merupakan teror yang harus dilawan dengan cara bekerja. Dengan demikian uang bisa didapat dalam jumlah yang mencukupi yang sekaligus berarti pula mereka bisa bermain secara baik di pasar.

Bila ditinjau dari sisi konsumen yang membeli komoditi untuk upacara yadnya tidak pula dapat dilepaskan dari ideologi pasar sehingga antara konsumen dan produsen terikat dari segi nilai ekonomi semata atau pragmatisme ekonomi. Kondisi seperti itu merupakan sebuah relasi kuasa dan uang ada di diantara keduanya. Menurut Atmaja (2009) bahwa masyarakat Bali kontemporer bahkan bangsa Indonesia pada umumnya telah terjebak dalam keadaan bangsa yang dangkal. Ciri bangsa yang dangkal adalah cenderung mengukur apa pun dengan uang dan mengubah apa pun jadi uang. Uang yang didapat bukan untuk kepentingan produktif, melainkan untuk konsumtif.

Menurut ( Triguna, 2004) karakter orang Bali telah mengalami perubahan secara signifikan. Orang Bali tidak lagi diidentifikasi sebagai orang yang lugu, sabar, ramah, dan jujur sebagaimana pernah digambarkan oleh Bateson. Demikian pula orang Bali tidak dapat dikategorikan sebagai komunitas inklusif, melainkan orang Bali telah dipersepsikan oleh outsider sebagai orang yang temperamental, egoistik, sensitif, dan cenderung menjadi human ekonomikus. Perubahan karakter orang Bali juga dipengaruhi moneterisasi (Triguna, 2004). Uang merupakan sarana ekonomi, tetapi saat digunakan dalam masyarakat dipahami sebagai fenomena sosiologis, cenderung kehilangan material dasarnya karena menjadi alat interaksi. Dalam sebagian besar orang Bali uang di samping lebih menjadi alat kegiatan ekonomi juga telah memasuki daerah budaya yang lebih luas.

Moneterisasi telah mempengaruhi perubahan mental di tingkat individu dan menciptakan beberapa budaya intelek di tingkat sosial. Budaya subjektifnya berubah dan menjadi bersifat objektif. Oleh karena uang sendiri adalah nilai dan dikejar oleh manusia, maka cenderung berubah fungsi dari alat menjadi akhir (Tuner, 1990). Dengan menggunakan analog agama, Simmel (Tuner, 1990) mengatakan bahwa moneterisasi sosial pada dasarnya sama dengan "pertumbuhan spiritualisasi uang" atau menurut istilah Karl Marx "fetisisme komoditas". Perbedaan kualitatifnya dari komoditas 
dibekukan menjadi bentuk uang sehingga uang dianggap sebagai sesuatu yang radikal, yang memiliki kapasitas membedakan segalanya secara kuantitas.

\section{c. Implikasi Sosial Budaya}

Manusia adalah makhluk individu dan makhluk sosial. Sebagai individu, manusia mempunyai kemauan dan kehendak yang mendorong dirinya berbuat dan bertindak. Selanjutnya dari apa yang diperbuat dan dari sikap hidupnya, manusia dapat mengetahui pribadi orang lain. Sebagai makhluk individu, manusia tentu ingin hidup senang, bahagia, dan menghindar dari segala yang menyusahkan. Akhirnya, manusia terdorong dan berusaha memenuhi segala kebutuhan hidupnya, baik kebutuhan jasmani maupun kebutuhan rohani yang dipandang dapat memberikan kesenangan dan kebahagiaan pada dirinya. Manusia sebagai makhluk individu, semua hak itu tidak bisa didapat dengan selalu hidup dalam kesendirian, tetapi harus berhubungan dengan manusia lainnya. Artinya, manusia di samping sebagai makhluk individu, juga sebagai makhluk sosial. Manusia hanya akan dapat hidup dengan sebaik-baiknya dan mempunyai arti apabila hidup bersama-sama dengan manusia lainnya dalam masyarakat. Hanya dalam hidup bersama, manusia dapat berkembang dengan wajar dan sempurna.

Koentjaraningrat (1992) menyatakan bahwa setiap manusia yang hidup dalam masyarakat akan terikat oleh suatu bentuk kesatuan sosial karena adanya ikatan wilayah atau tempat kehidupan. Sebagai suatu kesatuan hukum sosial, warga masyarakat biasanya mempunyai perasaan kesatuan yang dapat mewujudkan rasa kepribadian kelompok, yaitu perasaan bahwa kelompok tersebut mempunyai ciri-ciri kebudayaan yang berbeda dengan kelompok lain.

Sistem sosial masyarakat Bali memotivasi warga masyarakat untuk berorientasi kepada pentingnya nilai suka duka di dalam kehidupan bermasyarakat. Nilai suka duka tersebut memancar dalam semangat gotong royong yang tampak dalam aktivitas-aktivitas sosial. Di samping itu, nilai suka-duka merupakan refleksi dari solidaritas sosial yang muncul dari asas kebersamaan dan asas kekeluargaan. Hal itu mendorong warga masyarakat untuk menyelaraskan kehidupan dengan sesamanya yang dilandasi oleh ajaran tat twam asi. Gotong royong sebagai realisasi pernyataan solidaritas dalam persekutuan hidup bersama dalam kelompok sosial merupakan suatu proses yang mengarah kepada kegiatan sosialisasi. Maksudnya suatu proses belajar berperan sosial, belajar tentang norma-norma dalam masyarakat, dan belajar tentang nilai-nailai kepribadian. Dalam konteks ini tampak terdapat hubungan antara kewajiban dan hak, 
hubungan jasa dengan sanksi sosial, hubungan belajar dengan mengajar, dan hubungan pendidikan mental dengan perilaku (Majelis Pembina Lembaga Adat Daerah Tingkat I Bali, 1992/1993). Bagi masyarakat Bali memandang konsep sikap solidaritas sangat perlu ditumbuhkembangkan dalam kehidupan ini.

Ditinjau dari aspek sosiologis, manusia dalam hidupnya tidak dapat dipisahkan dengan interaksi sosial. Gilin and Gilin ( Triguna, 1994) mengatakan bahwa bentuk umum proses-proses sosial adalah interaksi sosial. Interaksi sosial merupakan syarat utama terjadinya aktivitas-aktivitas sosial. Selain itu, interaksi sosial juga merupakan hubungan sosial yang dinamis yang melibatkan hubungan, baik orang perorangan, antara kelompok dan kelompok, maupun antara orang perorangan dan kelompok. Proses interaksi sosial sering kali diawali dengan kontak dan komunikasi.

Beberapa persepsi tentang pesatnya perkembangan pariwisata di Pulau Bali akan berdampak pada lunturnya nilai kehidupan masyarakat di bawah kanopi falsafah tri hita karana. Menurut sudut pandang Naya (Sujana, 1994) manusia Bali kini berada di tengah perubahan sosial dan budaya atau di bawah pergeseran struktur sosial atau diliputi perkembangan sosial dan budaya yang kurang terkendali dan berhadapan dengan arus globalisasi yang deras dan intensif. Pendapat Naya Sujana berangkat dari pendekatan Antropologi dengan melihat masyarakat Bali memiliki kesadaran yang kuat tentang perjalanan sejarah, ikatan sosial, dan solidaritas, baik dalam arti individual maupun kolektif, tertanam suatu keyakinan bahwa sistem sosial budaya masyarakat Bali akan tetap lestari.

Sistem sosial masyarakat Hindu di Bali tergolong unik karena antara agama Hindu, adat istiadat, dan budaya memiliki kaitan yang erat. Masyarakat Bali juga beranggapan bahwa suatu kehidupan bernilai tinggi jika didasarkan atas asas kebersamaan, asas kekeluargaan, dan asas berbakti. Asas kebersamaan mendorong manusia untuk berorientasi pada sesamanya dan mewujudkan persatuan dan kesatuan, sedangkan asas berbakti menumbuhkan loyalitas untuk mengabdi pada keyakinan agama yang dianutnya. Rasa bakti masyarakat Hindu di Bali ditujukan dalam bentuk yadnya, yaitu kurban suci secara tulus ikhlas yang dipersembahkan ke hadapan Ida Hyang Widhi beserta manifestasi-Nya, manusa, dan alam lingkungannya. Berbagai yadnya yang dilaksanakan dapat menggerakkan dan mewujudkan perbuatan nyata dalam masyarakat berupa tolong-menolong, gotong royong, suka duka dalam kehidupan bermasyarakat dan melaksanakan aktivitas agama. 
Dalam upaya memahami kehidupan masyarakat Hindu di Kabupaten Tabanan, khususnya masyarakat Desa Bengkel tentu tidak bisa lepas dari sistem umat Hindu Bali secara umum. Berbagai rasa kecemasan, kekhawatiran, dan ketakutan terhadap lunturnya identitas serta jati diri sebagai umat Hindu yang santun, toleransi, ramah, jujur, dan lugu selalu menjadi wacana sosial. Namun, setelah mencoba masuk dalam kehidupan masyarakat Desa Bengkel, segala bentuk yang menjadi kekhawatiran lunturnya identitas orang Bali hingga saat sekarang ini secara umum inti hakikatnya masih tetap terjaga. Masyarakat Desa Bengkel baik individu maupun kolektif, masih konsisten menjaga keutuhan falsafah tri hita karana yang diyakini sebagai tiga hal yang menimbulkan kesejahteraan. Akan tetapi, dalam prosesnya sudah melalui suatu kemasan yang disesuaikan dengan perkembangan zaman. Pola hidup interaksi sosial kemasyarakatan sebagai salah satu bagian dari tri hita karana di Desa Bengkel perjalanannya masih membumi. Sikap kepekaan sosial yang terimplementasi dalam kehidupan toleransi, gotong royong, dan kasih sayang dijadikan sebagai prioritas utama. Hal tersebut sebagaimana penjelasan dari Perbekel Desa Bengkel (Wawancara 16 Mei 2019) sebagai berikut.

Masyarakat Desa Bengkel masihkuat kuat mempertahankan aktivitas pertanian. Tetapi juga banyak yang terlibat dalam kegiatan pekerjaan lain seperti sebagai penagawai negeri dan karyawan suwasta. Namun kehidupan sosial masyarakat tetap terjaga dalam suasana hidup gotong royong saling asah saling asuh. Masyarakat masih tetap menjalankan kewajiban, baik dalam kapasitas sebagai pribadi maupun kewajiban organisasi. Kewajiban organisasi hakikatnya masih tetap seperti dahulu seperti melaksanakan kewajiban ngayah ketika ada salah satu warga melaksanakan upacara yadnya. Hanya saja tekniknya dilakukan perubahan karena kita juga melihat perkembangan zaman. Kita tidak ingin karena urusan kewajiban organisasi menjadikan warga masyarakat dihambat waktu dan kesempatannya untuk mencari nafkah. Masyarakat Desa Bengkel sekarang sudah sangat menghargai waktu dan memang terikat pada waktu. Sehingga ketika ada salah satu dari masyarakat yang melaksanaan upacara yadnya, masyarakat yang lain, tetangga, terutama keluarga tetap eksis membantu menyelesaikan perlengkapan banten bahkan membantu nyumbang beberapa jenis perlengkapan banten seperti: lis, daksina, ketupat krosok. 
Pitana (1994) menjelaskan bahwa perubahan merupakan suatu fenomena yang selalu mewarnai perjalanan sejarah setiap masyarakat dan kebudayaannya. Setiap masyarakat selalu mengalami transformasi dalam fungsi waktu sehingga selalu terjadi perubahan dari masa ke masa. Di Desa Bengkel secara kasat mata identitas sebagai warga masyarakat Hindu Bali yang memiliki kepribadian saling asah saling asuh, salunglung sabayantaka dalam interaksi sosial kemasyarakatan secara kolektif masih terlihat berjalan dengan baik disebabkan oleh terikat pada adanya aturan (awig-awig). Jika salah seorang warga melaksanakan upacara yadnya yang dengan keterbatasan sarana prasarana, maka masyarakat menolong pun datang secara spontanitas tanpa diminta, walaupun tidak mempunyai hubungan keluarga. Sebagaimana penjelasan dari Winarcana (Wawancara, 27 Oktober 2019) berikut.

Warga masyarakat disini (Desa Bengkel) masih kuat hubungan jalinan sosialnya. Jika salah satu warga melaksanakan upacara yadnya maka warga lain dengan spontanitas memberi bantuan tanpa diminta. Dari mereka ada yang nyumbang sarana prasarana upacara yadnya seperti: klatkat, kelapa, busung dan yang lainnya. Bahkan ada yang nyumbang dalam bentuk yang sudah jadi seperti: lis, daksina, tamas, tupat krosok dan sebagainya yang semuanya dalam keadaan kering-kering. Hal itu disebabkan karena hampir setiap warga masyarakat pasti mempunyai bahan banten seperti itu sebagai persiapan melaksanakan suatu yadnya. Semua itu mereka kerjakan disela waktu luang sambil istirahat.

Dari penjelasan informan di atas, menunjukkan bahwa ketupat krosok sebagai bentuk budaya untuk aktivitas keagamaan, juga berfungsi sebagai media memperkuat jalinan hubungan sosial kemasyarakatan dalam ikut meringankan beban warga masyarakat. Di lain sisi dapat mengurangi waktu khusus untuk gotongroyong dalam mempersiapkan pembuatan banten upacara yadnya.

\section{d. Implikasi Ideologis}

Lull (Atmaja, 2009) menyatakan bahwa salah satu dimensi globalisasi adalah mengalirnya ideologi dari negara maju ke negara-negara sedang berkembang. Salah satu bentuk ideologi tersebut adalah kapitalisme, ideologi pasar, atau juga disebut dengan istilah agama pasar. Globalisasi yang menyatukan Bali dengan negara-negara kapitalisme mengakibatkan agama pasar dengan cepat masuk ke sistem sosiobudaya masyarakat Bali. Lebih-lebh Bali sebagai pusat pariwisata dunia menimbulkan implikasi agama pasar memperoleh penguatan, sebab pariwisata sebagai ethnoscape berintikan pada kegiatan bisnis. 
Ruang jangkauan agama pasar semakin luas sampai ke desa. Karakteristik agama pasar menjadikan uang sebagai objek tujuan. Bali sebagai salah satu bagian dari negara Indonesia yang sedang berkembang sangat berpeluang sebagai tempat berkembangnya agama pasar dan sangat mudah mendapatkan pengikut di tengah perkembangan pariwisata yang sangat maju. Dalam rangka menyalurkan hasrat atau keinginannya, agama pasar memiliki tempat suci, yakni pasar. Pasar menguasai manusia karena segala keinginan mereka bisa dipenuhi oleh pasar.

Menurut Marguire (2004), manusia yang terjerat pada agama pasar akan mengalami perubahan yang mendasar dalam sistem keyakinan mereka, yakni tidak lagi hanya berpegang pada monoteisme, tetapi bergeser ke arah moneytheisme, uang manjadi pujaan utama mereka dalam memenuhi kebutuhan sandang, pangan, dan papan, bahkan dapat pula dipakai sebagai alat memenuhi kebutuhan sosial, politik, budaya, dan psikologis. Kepemilikan atas uang dipandang dapat mengangkat harkat dan martabatnya dalam status sosial.

Kini pola seperti itu juga telah terjadi di Desa Bengkel sebagaimana penjelasan Jro Mangku Yuni (wawancara, 22 Oktober 2019) menjelaskan ketika melaksanakan upacara yadnya, hampir segala sarana prasarana upacara yadnya telah tersedia di pasarpasar, warung-warung. Bahkan para tukang banten yang sebelumnya ketika sebelumnya ada yang memesan atau ada yang minta tolong kemudian baru beraktivitas dibuatkan banten, namun sekarang dijadikan peluang bisnis dengan mendahului membuat segala jenis banten yang disimpan dirumahnya. Gejala seperti itu mencerminkan bahwa pengaruh agama pasar semakin mendalam terhadap masyarakat Desa Bengkel sehingga melakukan releksivitas terhadap tradisi, lalu menggantikannya dengan sesuatu yang lebih praktis.

Atmadja (2010) menjelaskan bahwa mencermati kehidupan orang Bali maka ada dua nilai yang dikaburkan, yakni nilai guna dan nilai simbolik. Apa yang dikonsumsi oleh orang Bali sering kali tidak didasarkan atas kebutuhan, tetapi pada keinginan. Akibatnya, orang Bali tidak menjadi user, tetapi menjadi consumer. Consumerisme tidak sematamata bertalian dengan anutan pada nilai simbolik, tetapi berkaitan pula dengan persoalan identitas. Pesatnya perkembangan arus modernisasi telah mennjukkan tanda-tanda merasuknya virus budaya konsumerisme terhadap masyarakat Desa Bengkel. Oleh karena itu, tren masyarakat Desa Bengkel membeli banten upacara yadnya di samping karena terbatasnya waktu, namun juga dari banten yang dibelinya sarat dengan tujuan agar 
mereka mendapat pengakuan dalam interaksi sosial dengan masyarakat lingkungan. Hal itu menunjukkan bahwa konsumsi menjadi sarana bagi seseorang untuk memahami dan berkomunikasi secara simbolik antara orang yang satu dan orang yang lain.

Ideologi yang diwarisi secara menstradisi oleh masyarakat Desa Bengkel tentang keyakinan filosofis terhadap penggunaan ketupat dalam upacara yadnya tidak berubah, tetapi ketika menggunakan ketupat dilandasi dengan pertimbangan rasional. Di antara sekian jenis ketupat dalam upacara yadnya, adalah ketupat sari yang mendominasi dipergunakan. Hampir setiap banten dilengkapi dengan ketupat sari. Menurut Gede Oka (Wawancara, 21 Oktober 2019) mengatakan, bahwa sesungguhnya ketupat yang digunakan adalah ketupat sari untuk melengkapi banten sorohan seperti banten panyeneng, banten caru, utamanya banten pejati. Penggunaan ketupat sari dalam banten panyeneng, banten caru maupun banten pejati, memunculkan dua nama yaitu ketupat krosok dan ketupat nasi. Penggunaan ketupat krosok dan ketupat nasi berlandaskan pada suatu pandangan dan keyakinan rasional. Masyarakat Desa Bengkel memaknai banten adalah simbol cinta kasih antara pemuja dengan yang dipuja. Sebagai wujud simbol cinta kasih dari Ida Sang Hyang Widhi Wasa terhadap umatnya, ketika selesai mempersembahkan banten selanjutnya dilungsur untk dinikmati (dimakan) salah satunya adalah ketupat sari yang selanjutnya disebut ketupat nasi (ketupat yang isinya matang) dilengkapi dengan lauk pauk. Ketupat ini biasanya melengkapi banten pejati yang dipersembahkan ka luhur yaitu di palinggih (tempat suci). Sedangkan ketupat sari dalam arti ketupat krosok, dipergunakan sebagai persembahan yang tidak untuk dilungsur (tidak dinikmati) seperti untuk persembahan bhuta yadnya/ caru yaitu persembahan ka sor (ke bawah). Secara psikologis yang dilandasi pertimbangan etika religius, masyarakat memandang dan meyakini segala sarana persembahan ke sor (bawah) tidak layak untuk dilungsur (dinikmati) karena untuk para kekuatan bhuta kala. Sehingga jika itu dilungsur (dinikmati) maka orang yang menikmati dikonotasikan sama dengan bhuta kala.

Beberapa keterangan dari masyarakat Desa Bengkel, Kecamatan Kediri, Kabupaten Tabanan, di era globalisasi ini dalam menjalankan kewajiban upacarakeagamaan menununjukkan adanya suatu gagasan simplikatif terhadap penggunaan ketupat. Dengan berbagai pertimbangan atas situasi dan keadaan sosial yang diahadapi masyarakat, akhirnya penggunaan ketupat dalam beberapa bentuk banten disederhanakan menjadi ketutap krosok, terutapa pada banten ketika selesai dipersembahkan tidak dilungsur/ dibuang. 


\section{Kesimpulan}

Penggunaan ketupat krosok di Desa Bengkel Kecamatan Kediri,Kabupaten Tabanan dalam menunjukkan adanya idiologi sebagai azas oleh warga masyarakat. Azas itu merupakan paham modernitas dari masyarakat yang diimplementasikan melalui menterapkan yang tidak menyimpang dari ajaran agama Hindu. Masyarakat menggunakan ketupat krosok tidak memarginalkan azas kesucian, namun dilandasi atas pertimbangan logika. Alasan ketupat krosok dipergunakan dalam upacara yadnya adalah karena pertimbangan praktis dan ekonomi, membeli lebih murah dari proses membuat, dan sewaktu-waktu mudah didapat. Implikasi religius penggunaan ketupat krosok bagi masyarakat Desa Bengkel, Kecamatan Kediri, Kabupaten Tabanan, bahwa keyakinan masyarakat dalam melaksanakan upacara yadnya tidak surut dan justru semakin antusias. Implikasi ekonomi bahwa masyarakat yang melaksanakan upacara yadnya secara ekonomi dapat menjalankan kewajibannya bekerja dengan pendapatan yang lebih menguntungkan daripada menyisihkan waktu khusus membuat ketupat dengan meninggalkan waktu bekerja. Di lain pihak merupakan peluang bisni bagi para tukang banten untuk mencari keuntungan. Implikasi dalam aspek sosial budaya, bahwa interaksi sosial hidup gotong-royong semakin tampak dengan saling bantu memberikan tawaran ketupat krosok di antara warga. Sedangkan implikasi ideologis, masyarakat cendrung lebih giat bekerja untuk mendapatkan uang. Masyarakat Desa Bengkel, Kecamatan Kediri, Kabupaten Tabanan, di era globalisasi dalam menjalankan kewajiban upacara keagamaan menununjukkan adanya suatu gagasan simplikatif terhadap penggunaan ketupat. Penggunaan ketupat dalam beberapa bentuk banten disederhanakan menjadi ketutap krosok, terutama pada banten ketika selesai dipersembahkan tidak dilungsur/ dibuang.

\section{Daftar Pustaka}

Adnyana, G. A. B. (2011). "Komersialisasi Banten Menciptakan Lapangan Pekerjaan”. Denpasar: Yayasan Manikgeni Dharma.

Ardika, I. W. (2008). Pariwisata dan Komodifikasi Kebudayaan Bali. Dalam Pusaka Budaya dan Nilai-Nilai Religiusitas. Denpasar: Jurusan Arkeologi Fakultas Sastra Universitas Udayana.

Atmadja, N. B. (2010). Bali pada Era Globalisasi Pulau Seribu Pura Tidak Seindah Penampilannya. Yogyakarta: LkiS.

Atmaja, N. B. (2009). Pelampiasan Syahwat Kekuasaan dan Ngutang Gae, Ngalih Gae: Pemahaman Elite Parpol dan Akar Rumput terhadap Pesta Demokrasi (Pilkada, 
Pilgub) di Bali dari Denotasi ke Ideologi. Makalah disampaikan dalam Seminar di Denpasar. Denpasar.

Koentjaraningrat. (1992). Pengantar Antropologi. Jakarta: Renika Cipta.

Lubis, A. Y. (2006). Dekonstruksi Epistemologi Modern: dari Posmodernisme, Teori Kritis, Poskolonialisme hingga Cultural Studies. Jakarta: Pustaka Indonesia Satu.

Mangunwijaya, Y. (1982). Sastra dan Religious. Jakarta: Sinar Harapan.

Picard, M. (2006). Pariwisata Budaya dan Budaya Parwisata. Penerjemah Jean Couteau dan Warih Wisatsana. Jakarta: Kepustakaan Populer Gramedia- Forum JakartaParis, Ecols Francaise d'extreme-orient.

Pitana, I. G. (1994). Mosaik Masyarakat dan Kebudayaan Bali. Denpasar: BP.

Sudibya, I. G. (1994). Hindu Menjawab Dinamika Zaman. Denpasar: BP.

Sujana, N. N. (1994). Kompleksitas dan Dinamika di Tengah Bangunan Kebudayaan Bali. Denpasar: Bali Post.

Sztompka, P. (2007). Soiologi Perubahan Sosial (Alimandan, Ed.). Jakarta: Media Group.

Triguna, Ida Bagus Gde Yudha. (2004). Kecenderungan Perubahan Karakter Orang Bali dalam Politik Kebudayaan dan Identitas Etnik. Ardika I Wayan dan Darma Putra, Nyoman editor. Denpasar: Fakultas Sastra Universitas Udayana. dan Balimangsi Press.

Triguna, Ida Bagus Gede Yudha. (1994). Pergeseran dalam Pelaksanaan Agama:Menuju Tattwa. Dalam Dinamika Masyarakat dan Kebudayaan Bali (I. G. Pitana, Ed.). Denpasar: Bali Post.

Tuner, B. (1990). Max Weber : From History to Modernity. London: Roulegne.

Wiana, I. K. (2006). Berbisnis Menurut Agama Hindu. Surabaya: Paramita. 